\title{
PENGARUH PEMBERIAN MANUR BROILER DENGAN FERMENTASI Lactobacillus casei TERHADAP KONVERSI PAKAN AYAM KAMPUNG
}

\section{The Effect of Broiler Manure with Lactobacillus casei Fermentation on the Kampung Chicken Feed Convertion Ratio}

\author{
Alfarisa Nururrozi ${ }^{1}$, Soedarmanto Indarjulianto ${ }^{1}$, Dhasia Ramandani ${ }^{2}$, Yanuartono ${ }^{1, *}$ \\ ${ }^{1}$ Dept. IImu Penyakit Dalam, Fakultas Kedokteran Hewan, Universitas Gadjah Mada \\ ${ }^{2}$ Dept. Teknologi Hayati dan Veteriner, Sekolah Vokasi, Universitas Gadjah Mada \\ JI.Fauna No 2, Kampus UGM, Karangmalang, Yogyakarta. \\ *Email: yanuartono20@yahoo.com
}

\begin{abstract}
Husbandry of kampung chicken is constrained by high feed prices and poor productivity. This study aims to utilize alternative feed materials derived from broiler manure to obtain a cheaper feed with good quality. Manure contains high nutrients. Manure was fermented using Lactobacillus casei to improve feed conversion. Two hundred chickens were divided into 4 groups $(n=50)$. Groups $P 1, P 2$, and $P 3$ were given $4 \%, 8 \%$, and $12 \%$ fermentation of L. casei, respectively. Group PO was given a regular feed without L. casei. Each treatment group consisted of four replicates and were maintained for 60 days. The research design used was Completely Randomized Design subjected to analysis of variant (ANOVA) followed by Duncan test. The feed conversion values of groups $P 0, P 1, P 2$, and $P 3$ were 4.46; 4.38; 4.21; and 4.54, respectively. The results showed that the feed conversion was not significant in all groups. It was concluded that $L$. casei fermenter could not improve the feed conversion ratio (FCR).
\end{abstract}

Keywords: FCR, fermentation, kampung chicken, Lactobacillus casei, manure

\section{ABSTRAK}

Budidaya ayam kampung terkendala tingginya harga pakan dan rendahnya produktivitas. Penelitian ini bertujuan memanfaatkan pakan alternatif bersumber manur (limbah kotoran) ayam broiler untuk memperoleh pakan murah dengan kualitas baik. Manur broiler masih mengandung nutrisi yang tinggi. Manur difermentasi menggunakan Lactobacillus casei untuk memperbaiki konversi pakan. Dua ratus ekor ayam dibagi menjadi 4 kelompok ( $\mathrm{n}=50$ ekor). Kelompok P1, P2, dan P3 masing-masing diberi ransum yang ditambah fermentasi $L$. casei sebanyak $4 \%, 8 \%$, dan $12 \%$. Kelompok P0 diberikan pakan biasa tanpa penambahan $L$. casei. Setiap kelompok perlakuan terdiri dari empat ulangan dipelihara selama 60 hari. Penelitian menggunakan Rancangan Acak Lengkap (RAL) dengan analisis ragam yang dilanjutkan dengan uji Duncan. Konversi pakan dari kelompok P0, P1, P2, dan P3 berturutturut 4,$46 ; 4,38 ; 4,21$; dan 4,54 . Hasil penelitian menunjukkan konversi pakan tidak berbeda nyata pada semua kelompok perlakuan. Dari hasil penelitian disimpulkan penggunaan fermenter L.casei pada pakan belum mampu memperbaiki konversi pakan.

Kata Kunci: ayam kampung, FCR, fermentasi, Lactobacillus casei, manur 


\section{PENDAHULUAN}

Permasalahan utama dalam budidaya ayam kampung adalah rendahnya konversi pakan dan mahalnya harga pakan pabrikan (Dewanti dan Sihombing 2012; Hidayat 2012; Munira et al. 2016). Mahalnya harga pakan dapat diatasi dengan memanfaatkan bahan pakan alternatif bersumber limbah industri untuk memperoleh pakan murah dengan kualitas yang tetap terjaga (Baruah dan Bhatt 2008; Suryana dan Hasbianto 2008; Hidayat 2012). Limbah industri yang jumlahnya melimpah dan berpotensi sebagai pakan alternatif, salah satunya adalah manur digestat kotoran ayam broiler (Pamungkas et al. 2012; Ghaly dan MacDonald 2012). Manur digestat adalah limbah budidaya ternak baik dalam bentuk segar maupun sekam (alas kandang) yang terdekomposisi bersama bulu, sisa pakan yang tumpah, dan limbah organik lain dalam bentuk solid atau cairan (Baruah dan Bhatt 2008; Pamungkas et al. 2012; Ghaly dan MacDonald 2012).

Manur ayam broiler sebagai limbah peternakan ternyata masih mempunyai kandungan nutrisi yang baik (Pamungkas et al. 2012; Ghaly dan MacDonald 2012). Manur ayam broiler mengandung protein dari pakan yang tidak tercerna dengan jumlah yang masih tinggi (Ghaly dan MacDonald 2012). Protein tersebut terbuang melalui kotoran akibat tidak sempat tercerna dengan sempurna. Berdasarkan penelitian yang dilakukan oleh Pamungkas (2012) yang menguji pemberian pakan bersumber kotoran ayam broiler terfermentasi untuk pakan alternatif, didapatkan hasil yang baik.

Manur ayam broiler dapat difermentasi terlebih dahulu dengan tujuan meningkatkan kandungan protein, palatabilitas, dan membunuh mikroorganisme patogen (Lokapirnasari et al. 2016). Proses fermentasi dapat dilakukan menggunakan bakteri asam laktat (probiotik). Salah satu bakteri probiotik yang banyak digunakan adalah Lactobacillus casei. Penelitian Sunaryanto et al. (2014) menunjukkan bahwa $L$. casei isolat lokal memiliki potensi untuk digunakan sebagai mikroba probiotik. L. casei mampu hidup sampai dengan konsentrasi garam empedu $15 \%$, tahan terhadap media asam sampai dengan $\mathrm{pH} 2$, memiliki aktivitas antimikroba dengan menghambat pertumbuhan Escherichia coli,
Staphylococcus aureus, dan Enterococcus faecalis (Sunaryanto et al. 2014)

Penelitian lain menyebutkan proses fermentasi pada manur menggunakan $L$. casei mampu meningkatkan kandungan protein (Ghaly dan MacDonald 2012). Penelitian oleh Sunaryanto et al. (2014) yang menggunakan manur ayam petelur dengan fermenter Aspergillus niger, mampu meningkatkan kadar protein dari 9,84\% menjadi $15,31 \%$. Pemberian pakan dari bahan kotoran ayam broiler yang difermentasi $A$. niger hingga konsentrasi 6\% aman digunakan dan mampu menghasilkan pertambahan berat badan pada ayam broiler yang baik dengan FCR 1,6 (El Deek et al. 2009; Pamungkas et al. 2012). Penelitian ini bertujuan untuk mengetahui pengaruh pemberian pakan berbahan manur broiler yang difermentasi menggunakan $L$. casei terhadap konversi pakan (Feed Convertion Rasio-FCR) pada ayam kampung.

\section{BAHAN DAN METODE}

\section{Tempat dan waktu penelitian Penelitian} Penelitian dilaksanakan di Laboratorium Departemen Ilmu Penyakit Dalam, Fakultas Kedokteran Hewan, Universitas Gadjah Mada untuk menyiapkan isolat dan fermenter. Pemeliharaan ayam dilakukan di kandang ayam Dusun Janten, Kecamatan Wates, Kulon Progo. Kandang yang digunakan adalah sistem petak menggunakan litter. Penelitian dilakukan selama empat bulan mulai dari Agustus hingga November 2017. Tahapan penelitian terdiri dari: 1. persiapan isolat $L$. casei, 2. pembuatan feed additive berbahan manur, 3 . pemberian feed additive, 4. penimbangan dan koleksi data, 5. analisis hasil.

\section{Persiapan isolat $L$. casei}

Isolat $L$. casei didapatkan dari Laboratorium Pusat Antar Universitas (PAU UGM). Persiapan fermenter dilakukan dengan menumbuhkan biak murni $L$. casei dalam media cair dengan komposisi akuades steril 1 liter, urea $10 \mathrm{~g}, \mathrm{KH}_{2} \mathrm{PO} 45 \mathrm{~g}, \mathrm{MgSO}_{4}$ $0,5 \mathrm{~g}, \mathrm{CaCO}_{3} 10 \mathrm{~g}$, molases (dekstrose) $50 \mathrm{~g}$, dan tepung kentang sesuai yang dijelaskan Pamungkas et al. (2012). Kentang sebanyak $250 \mathrm{~g}$ yang sudah bersih dan dipotongpotong, direbus selama 20 menit kemudian disaring sampai dihasilkan filtrat sebanyak 1 
liter dengan penambahan akuades steril. Larutan filtrat ditambah dengan bahan-bahan lain, kemudian dituangkan ke dalam 5 Erlenmeyer berisi $200 \mathrm{~mL}$ air filtrat, setelah itu dimasukkan ke dalam autoklaf selama 15 menit pada suhu $121^{\circ} \mathrm{C}$ dengan tekanan 1,5 psi. Campuran media disterilisasi dengan autoklaf dengan tujuan untuk menghilangkan kontaminan sebelum digunakan untuk media kultur. Pada Erlenmeyer dimasukkan isolat $L$. casei dengan konsentrasi masing-masing sebesar $1 \times 10^{9} \quad \mathrm{sel} / \mathrm{mL}$, kemudian digoncangkan pada shaker dengan kecepatan $60 \mathrm{rpm}$. Campuran biak murni $L$. casei dengan media pertumbuhan disimpan dalam kondisi anaerob pada suhu kamar selama 14 hari. Biakan $L$. casei yang telah tumbuh pada media pertumbuhan cair (Gambar 1A) digunakan untuk membuat pakan menggunakan manur ayam broiler.
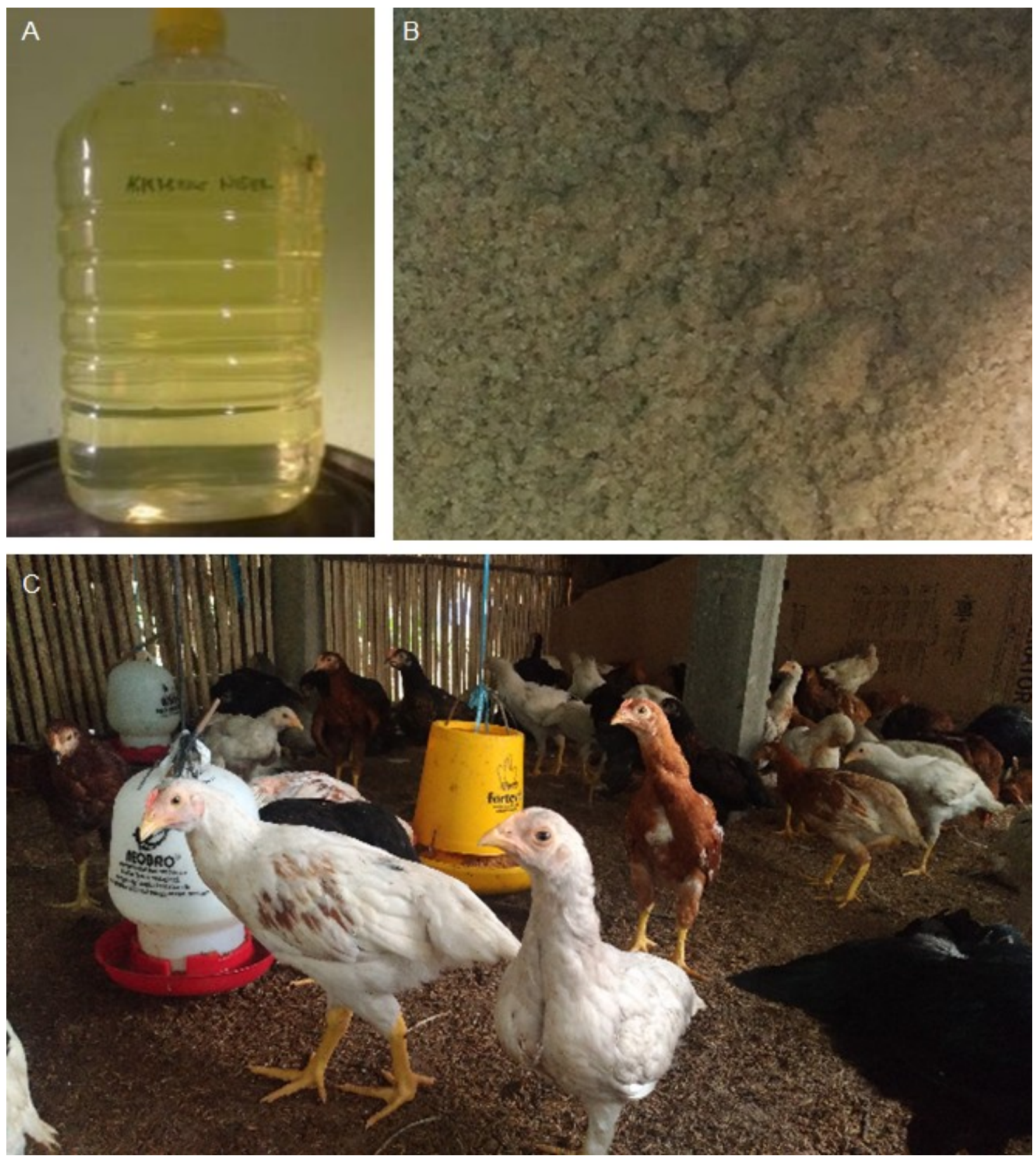

Gambar 1. Isolat cair Lactobacillus casei (A), pakan hasil fermentasi menggunakan Lactobacillus casei (B), dan ayam kelompok perlakuan (C) 
Ayam

Materi dalam penelitian ini menggunakan 200 ekor day old chick (DOC) ayam kampung dengan berat badan awal $32,13 \pm 5,33$ gram. Ayam diseleksi dengan cara memilih berdasarkan bobot badan seragam untuk mendapatkan obyek penelitian yang homogen.

Ayam dibagi secara acak kedalam 4 kelompok yaitu P0, P1, P2, P3 (masingmasing 50 ekor) dan diberi nomor yang ditempelkan pada sayap. Ayam dipelihara di kandang berlantai litter (Gambar 1C) sampai umur empat hari dengan perlakuan sama dengan pemberian pakan secara ad libitum sebelum masuk masa perlakuan penelitian.

\section{Pembuatan feed additive berbahan manur}

Pembuatan bahan pakan menggunakan $200 \mathrm{~kg}$ manur digestat ayam broiler yang telah kering, kemudian dihancurkan teksturnya hingga menjadi remah dengan mixer. Kotoran ayam yang telah lembut diratakan ke dalam terpal dengan tinggi sekitar $15 \mathrm{~cm}$. Manur digestat yang digunakan memiliki kadar air minimal $30 \%$ untuk memudahkan proses pertumbuhan L. casei. Fermenter cair yang berisi inokulum $L$. casei disiramkan merata pada manur digestat. Campuran manur digestat dan fermenter $L$. casei dicampur dengan cara dibolak balik hingga homogen, selanjutnya ditutup dengan terpal sampai terjadi proses fermentasi (Gambar 1B).

\section{Pemberian pakan}

Kelompok P0 (kontrol) diberi pakan dan minum sesuai dengan standar umur pertumbuhan ayam. Kelompok P1, P2, dan P3 masing-masing diberi ransum yang ditambah fermentasi $L$. casei. Perlakuan level pemberian yang digunakan adalah sebagai berikut:

$\mathrm{PO}=$ fermentasi manur broiler $0 \%$

$\mathrm{P} 1=$ fermentasi manur broiler $4 \%$

$\mathrm{P} 2$ = fermentasi manur broiler $8 \%$

$\mathrm{P} 3=$ fermentasi manur broiler $12 \%$

Penambahan feed additive $L$. casei diberikan sehari sekali yang dilakukan mulai hari ke-7 pemeliharaan hingga panen. Pemeliharaan dilakukan selama 60 hari dengan pemberian pakan sesuai dengan standar strain ayam kampung (Munir et al. 2017). Pada periode starter pakan yang diberikan jenis BR I (Comfeed, PT Japfa Comfeed-Indonesia) berbentuk tepung.
Tabel 1. Hasil analisis kandungan nutrien bahan penyusun ransum pakan yang digunakan

\begin{tabular}{|c|c|c|}
\hline Nutrisi & Fase starter & Fase akhir \\
\hline $\begin{array}{l}\text { Metaboliisme energi } \\
\text { /ME (kkal/kg) }\end{array}$ & 3000 & 3050 \\
\hline Protein kasar (\%) & 21 & 19 \\
\hline Serat kasar (\%) & $4-4,5$ & 5 \\
\hline $\mathrm{Ca}(\%)$ & 1 & 0,9 \\
\hline $\mathrm{P}(\%)$ & 0,45 & 0,42 \\
\hline
\end{tabular}

Pakan periode finisher menggunakan pakan BR II (Comfeed, PT Japfa ComfeedIndonesia) berbentuk crumble. Air minum diberikan secara ad libitum. Kandungan nutrien bahan penyusun ransum dan komposisi pakan berdasarkan perlakuan ditunjukkan pada Tabel 1.

\section{Penimbangan dan koleksi data}

Parameter performa ayam yang diamati meliputi perhitungan konsumsi pakan, pertambahan berat badan, dan konversi pakan. Konsumsi pakan merupakan jumlah pakan yang dihitung setiap hari dengan cara menghitung pakan yang diberikan dikurangi sisa pakan (g/ekor/hari). Pertambahan bobot badan (g/ekor) ayam broiler ditimbang setiap minggu untuk mendapatkan data bobot badan, data total PBB didapat dari penimbangan bobot badan akhir dikurangi bobot badan awal. Konversi pakan dihitung dari jumlah pakan yang dikonsumsi dibagi dengan PBB.

\section{Analisis hasil}

Data yang diperoleh dianalis secara statistik menggunakan program SPSS. Data dianalisa dengan anova, dan jika ada perbedaan antara perlakuan diuji dengan uji jarak berganda Duncan.

\section{HASIL DAN PEMBAHASAN}

Perkembangan berat badan ayam dihitung melalui rumus perhitungan Average Daily Gain (ADG) untuk mengetahui ratarata perkembangan berat badan setiap kelompok ayam per minggu. Data hasil penelitian pengaruh penambahan $L$. casei yang dicampur ke dalam manur digestat terhadap performa ayam kampung yang meliputi rata-rata konsumsi pakan, pertambahan bobot badan, dan konversi pakan dapat dilihat pada Tabel 2. 
Tabel 2. Rata-rata konsumsi pakan, pertambahan bobot badan, dan konversi pakan selama penelitian (60 hari)

\begin{tabular}{lcccc}
\hline \multirow{2}{*}{ Variabel } & \multicolumn{4}{c}{ Perlakuan } \\
\cline { 2 - 5 } & P0 & P1 & P2 & P3 \\
\hline Konsumsi pakan (g/ekor) & $4150 \pm 170,4$ & $4230 \pm 150$ & $3980 \pm 180,3$ & $4180 \pm 210,2$ \\
PBB (g/ekor) & $930 \pm 45$ & $965 \pm 40$ & $945 \pm 85$ & $920 \pm 100$ \\
Konversi pakan & $4,46 \pm 0,12$ & $4,38 \pm 0,09$ & $4,21 \pm 0,10$ & $4,54 \pm 0,07$ \\
\hline
\end{tabular}

Keterangaan : Notasi superskrip yang berbeda pada baris yang sama menunjukkan perbedaan pengaruh sangat nyata $(P<0,05)$

\section{Konsumsi pakan}

Berdasarkan hasil penelitian terhadap total konsumsi pakan, tidak terdapat perbedaan secara nyata $(P<0,05)$ pada $P 0$, P1, P2, dan P3. Total konsumsi pakan pada kelompok P0 (kontrol) tanpa penambahan manur terfermentasi adalah 4150 g/ekor/60 hari. Total konsumsi pakan pada kelompok yang diberi tambahan fermentasi manur dengan level 4\% (P1), 8\% (P2), dan 12\% (P3) berturut-turut adalah 4230; 3980; dan 4180 g/ekor/60 hari. Tidak ada standar yang jelas kebutuhan pakan ayam kampung yang dipelihara secara semi intensif dikarenakan pakan berupa kombinasi konsentrat dan pakan dari lingkungan. Kelompok yang memiliki total konsumsi pakan terendah adalah kelompok dengan penambahan fermentasi manur 8\% (P2), sedangkan kelompok penambahan fermentasi manur 12\% (P3) memiliki total konsumsi pakan tertinggi. Menurut penelitian Jaya (2012) dan Mahardika et al. (2014), konsumsi pakan pada ayam kampung yang dipelihara menggunakan kandang open house system adalah 43506500 gram/ekor/60 hari tergantung dari kualitas pakan, strain ayam, dan metode pemeliharaan.

\section{Pertambahan berat badan}

Berdasarkan hasil penelitian terhadap pertambahan berat badan, tidak terdapat perbedaan secara nyata $(P<0,05)$ pada $P 0$, $\mathrm{P} 1$, P2, dan P3. Total pertambahan berat badan pada kelompok P0 (kontrol) tanpa penambahan manur terfermentasi adalah 930 g/ekor/60 hari. Total pertambahan berat badan pada kelompok yang diberi tambahan fermentasi manur dengan level 4\% (P1), 8\% (P2), dan $12 \%$ (P3) berturut-turut adalah 965; 945; dan 920 g/ekor/60 hari

Berdasarkan hasil penelitian dapat diketahui bahwa penambahan manur terfermentasi dengan perlakuan $4 \%$ dan $8 \%$ memiliki bobot badan yang lebih baik dibandingkan kelompok kontrol (P0) dan perlakuan $12 \%$ (P3), namun secara statistik tidak signifikan $(P<0,05)$. Pertambahan bobot bada sangat dipengaruhi oleh kandungan protein pada ransum. Menurut Pamungkas et al. (2012), protein merupakan zat yang paling penting bagi ayam untuk proses pembentukan sel-sel baru dan perbesaran ukuran sel yang akan menyebabkan peningkatan berat badan.

\section{Konversi pakan}

Pengaruh penambahan manur sebagai bahan campuran ransum dapat dilihat dari konversi pakan. Nilai konversi pakan melibatkan perbadingan antara konsumsi ransum dan pertambahan berat badan (Iskandar 2010). Semakin kecil nilai konversi pakan, berarti semakin efisien kemampuan ternak dalam mencerna pakan, maka berarti semakin sedikit pula pakan yang diperlukan untuk mencapai pertambahan per satu kilogram bobot badan (Hidayat 2012).

Nilai FCR dari kelompok P0, P1, P2, dan P3 berturut-turut 4,46; 4,38; 4,21; dan 4,54. Hasil penelitian menunjukkan hasil tidak berbeda nyata $(P<0,05)$ pada semua kelompok perlakuan. Standar FCR ayam kampung yang dikatakan baik pada pemeliharaan hingga hari ke-60 adalah sekitar 4-6. Kelompok P2 memiliki nilai konversi pakan yang terbaik disebabkan karena total konsumsinya yang lebih sedikit rerata berat panen yang paling baik. Dari hasil penelitian diketahui penambahan manur terfermentasi menggunakan $L$. casei level 4\% (P1), dan 8\% (P2) pakan mampu memperbaiki konsumsi pakan dan memperbaiki FCR pada ayam kampung meskipun secara statistik tidak signifikan. 


\section{Pembahasan}

Berdasarkan data penelitian diatas, penambahan $L$. casei dengan berbagai level tidak berpengaruh terhadap palatabilitas manur, sehingga total konsumsi pakan memiliki nilai yang relatif sama. Menurut Suryana dan Hasbianto (2008), tinggi rendahnya jumah konsumsi pakan akan sangat dipengaruhi oleh palatabilitas pakan itu sendiri. Hasil penelitian menunjukkan bahwa penambahan manur yang telah difermentasi dengan $L$. casei hingga level $12 \%$ tidak mampu mempengaruhi konsumsi ransum ayam kampung secara signfikan.

Pengamatan penambahan manur terfermentasi dengan perlakuan $4 \%$ dan $8 \%$ memiliki bobot badan yang lebih baik dibandingkan kelompok kontrol. Proses fermentasi anaerobik yang dilakukan pada penelitian ini diduga mampu meningkatkan kandungan nutrisi dari manur. Penelitian oleh Pamungkas et al. (2012) menjelaskan bahwa proses fermentasi pada manur ayam petelur mampu meningkatkan kandungan protein kasar sebesar $55 \%$. Hal ini disebabkan karena terjadi proses fermentasi anerobik yang dilakukan oleh bakteri metanogen (Pambudi 2008). Penelitian lain oleh Raharjo et al. (2012), menyebutkan bahwa pakan yang difermentasi akan meningkatkan nilai gizi, memiliki cita rasa yang lebih baik, lebih mudah dicerna, serta menghambat pertumbuhan mikroorganisme patogen di dalam pakan. $L$. casei akan mengaktivasi enzim amilase dan protease sehingga menghasilkan kadar asam amino yang lebih tinggi dibanding manur yang tidak difermentasi (Jaya 2012; Lokapirnasari et al. 2016).

Nilai konversi pakan kelompok perlakuan yang didapatkan pada penelitian ini lebih baik dibandingkan kelompok kontrol, meskipun secara statistik tidak berbeda signifikan. Menurut Lokapirnasari et al. (2016), penambahan $L$. casei yang merupakan bakteri asam laktat mampu memperbaiki penyerapan nutrisi dari ransum melalui peningkatan sekresi enzim pencernaan, misalnya enzim pepsin, yang mampu menghidrolisis protein sehingga memudahkan tubuh ayam menyerap protein (Lokapirnasari et al. 2016). Penurunan konversi pakan pada penelitian ini dipengaruhi penambahan $L$. casei pada pakan. Menurut penelitian Lokapirnasari et al. (2016) penambahan probiotik asam laktat dengan konsentrasi $1 \%$ dapat menurunkan konversi pakan ayam pedaging.

Penambahan $L$. casei terbukti juga dapat membantu proses pencernaan. Berdasarkan SNI 2981 : 2009, dijelaskan bahwa jumlah bakteri probiotik yag dibutuhkan untuk membantu proses pencernaan adalah $1 \times 10^{7} \mathrm{sel} / \mathrm{ml}$, sehingga terbentuk keseimbangan mikroorganisme yang didominasi mikroorganisme non patogen dalam saluran pencernaan (Soeharsono et al. 2010).

Penelitian yang dilakukan Raharjo et al. (2012) menunjukkan pakan yang difermentasi dengan $L$. casei mampu meningkatkan berat badan ayam broiler dengan FCR yang lebih baik dibanding kelompok kontrol. Penambahan $L$. casei akan menyediakan fitase sehingga mampu memecah asam fitat yang merupakan zat anti nutrisi pada pakan unggas. Keberadaan asam fitat inilah yang membentuk kompleks dengan protein dan asam amino sehingga menyebabkan penurunan kecernaan protein (Kim et al. 2006). Penelitian ini menunjukkan berat badan dan konversi pakan pada kelompok perlakuan tidak lebih baik, salah satunya karena karakteristik pertumbuhan ayam kampung yang tidak sebaik pada ayam broiler.

Asam fitat memiliki kemampuan berikatan dengan protein pada $\mathrm{pH}$ asam, alkalis, maupun netral (Sabha 2008). Interaksi antara asam fitat dan protein menyebabkan penurunan kelarutan protein dan akhirnya menyebabkan penurunan penggunaan protein. Fitat juga dapat membentuk kompleks dengan protease seperti tripsin dan peptin dalam saluran pencernaan sehingga dapat mengurangi aktivitas enzim pencernaan yang berakibat pada penurunan kecernaan protein dan energi (Akyurek et al. 2005). Pemecahan ikatan asam fitat dapat dilakukan dengan penambahan fitase secara buatan.

Fitase (myo-inositol hexakisphosphate phosphohydrolase) merupakan golongan fosfatase yang memiliki kemampuan secara in vitro untuk membebaskan minimal satu ikatan fosfat dari asam fitat sehingga melepaskan fosfat dan menurunkan fosfatinositol yang berpotensi mengikat mineral (Greiner dan Konietzy 2006). Unggas tidak mempunyai fitase dalam 
saluran pencernaannya (Kim et al. 2006). Penambahan mikroorganisme penghasil fitase dalam pakan diharapkan dapat memecah ikatan kimia asam fitat sehingga penyerapan pakan pada ayam kampung menjadi lebih baik.

Menurut El-Deek et al. (2009), penambahan fitase dari mikrobia pada pakan dapat meningkatkan produktivitas ayam. Fitase dapat diproduksi dari fermentasi beberapa jenis mikroorganisme seperti Lactobacillus sp, Aspergillus niger, dan S. cerevisiae dalam media dasar berupa jagung (Tang et al. 2010). L. casei merupakan jenis mikroorganisme yang diakui aman oleh lembaga FDA (Food and Drug Administration) dan digolongkan sebagai GRAS (Generally Recognized As Saved) (Greiner dan Konietzny 2006). Fitase yang diproduksi oleh jenis mikroorganisme tersebut aman dan berpotensi digunakan secara luas dalam dunia perunggasan.

\section{KESIMPULAN}

Hasil penelitian menunjukkan hasil konversi pakan berbeda tidak nyata pada semua kelompok perlakuan. Dari hasil penelitian disimpulkan penggunaan fermenter L.casei pada pakan dengan level $4 \%, 8 \%$, dan $12 \%$ belum mampu memperbaiki konversi pakan ayam kampung.

\section{UCAPAN TERIMAKASIH}

Proyek penelitian ini sepenuhnya terselenggara atas Hibah Iptek Bagi Masyarakat yang didanai oleh Direktorat Riset dan Pengabdian Masyarakat, Direktorat Jenderal Penguatan Riset dan Pengembangan Kementerian Riset, Teknologi, dan Pendidikan Tinggi dengan judul "Feed Additive Berbasis Fermentasi Manur Digestat Kotoran Ayam Menggunakan Lactobacillus casei untuk Meningkatkan Produktivitas Ayam Kampung", sesuai Surat Penugasan Pelaksanaan Pekerjaan Nomor 001/SP2H/PPM/DRPM/IV/2017 dari Direktorat Pengabdian Kepada Masyarakat Universitas Gadjah Mada, Yogyakarta, Indonesia.

\section{DAFTAR PUSTAKA}

Akyurek H, Senkoylu N, Ozduven ML (2005)
Effect of microbial phytase on growth performance and nutrients digestibility in broilers. Pak J Nutr 4:22-26. doi: 10.3923/pjn.2005.22.26

Baruah MS, Bhatt BP (2008) Recyling of caged layer manure as broiler feed. Indian Vet J 85:293-295

Dewanti R, Sihombing G (2012) Analisis pendapatan usaha peternakan ayam buras. Bul Peternakan 36:48-56. doi: 10.21059/buletinpeternak.v36i1.1276

El-Deek AA, Osman M, Yakout HM, Yahya E (2009) Response of broilers to microbial phytase supplementation as influenced by dietary corn gluten meal levels. Egypt Poult Sci 29:77-97

Ghaly AE, MacDonald KN (2012) Drying of poultry manure for use as animal feed. Am J Agri Biol Sci 7:239-254. doi: 10.3844/ajabssp.2012.239.254

Greiner R, Konietzny U (2006) Phytase for food application. Food Technol Biotechnol 44:125-140

Hidayat C (2012) Pengembangan produksi ayam lokal berbasis bahan pakan lokal. Wartazoa 22:85-98

Iskandar S, (2010) Usaha tani ayam kampung. Balai Penelitian Ternak Ciawi, Bogor

Jaya TP (2012) Pengaruh probiotik (kombinasi bakteri Lactobacillus $\mathrm{sp}$, Saccharomyces cerevisiae, Streptomyces albus, Bacillus subtilis) terhadap konversi pakan ayam pedaging. Skripsi, Universitas Airlangga

Kim T, Mullaney EJ, Porres JM, Roneker KR, Crowe S, Rice S, Ko T, Ullah AHJ, Daly, CB, Welch R, Lei XG (2006) Shifting the $\mathrm{pH}$ profile of Aspergillus niger PhyA Phytase to match the stomach $\mathrm{pH}$ enhances its effectiveness as an animal feed additive. Appl Environ Microbiol 72:4397-4403. doi: 10.1128/AEM.02612-05

Lokapirnasari WP, Rahmawati A, Elliyani $\mathrm{H}$, (2016) Potensi penambahan bakteri asam laktat Lactobacillus casei dan Lactobacillus rhamnosus terhadap konsumsi pakan dan konversi pakan ayam pedaging. J Agro Vet 5:43-49

Mahardika IG, Kristina Dewi GAM, Sumadi IK, Suasta IM (2014) Kebutuhan energi dan protein untuk hidup pokok dan pertumbuhan pada ayam kampung 
umur 10-20 minggu. Majalah IImiah Peternakan 16:6-11. doi: 10.24843/MIP.2013.v16.i01. p02

Munir IM, Haryani D, Amin N, Kardiyanto E, Alfarizi MA, Makmur A, Kusumawati S (2017) Kajian pengembangan ayam kampung unggul Badan Litbang Pertanian (KUB) di Provinsi Banten 2016. Laporan Akhir Kegiatan 2016. Balai Pengkajian Teknologi Pertanian Banten. Kementerian Pertanian. doi: 10.13140/RG.2.2.24339.48166

Munira S, Nafiu LO, Tasse AM (2016) Performans ayam kampung super pada pakan yang disubttusi dedak padi fermentasi dengan fermentor berbeda. Jitro 3:21-29

Pambudi NA (2008) Pemanfaatan biogas sebagai energi alternatif. http://www.dikti.org. Diakses 18 Januari 2018

Pamungkas GS, Sutarno, Mahajoeno E (2012) Fermentasi lumpur digestat kotoran ayam petelur dengan kapang Aspergillus niger untuk sumber protein pada ransum ayam. J Bioteknol 9:2634. doi: 10.13057/biotek/ c090105

Raharjo S, Faridz F, Munandar A, Saputro, FR, Arifin M (2012). Produksi crude Aspergillus fermentation guna meningkatkan kualitas bahan pakan sebagai pemacu produktivitas ayam kampung super. Skripsi, Universitas Gadjah Mada

Sabha R (2008) Effect of different level of phytase on broilers performance and body status of phosporus. Thesis, An Najah National University, Nablus, Palestine

SNI (2006) Pakan Ayam Ras Pedaging Masa Akhir (broiler finisher). Standar Nasional Indonesia. SNI 01-3931-2006. Badan Standarisasi Nasional, Jakarta, hlm 2

Soeharsono, Adriani L, Safitri R, Sjofjan O, Abdullah S, Rostika R, Lengkey HAW, Mushawwir A (2010) Probiotik: Basis IImiah, Aplikasi dan Aspek Praktis. Widya Padjajaran, Bandung

Sunaryanto R, Martius E, Marwoto B (2014) Uji kemampuan Lactobacillus casei sebagai agensia probiotik. J Bioteknol Biosains Indones 1:9-14. doi: 10.29122/jbbi.v1i1.546

Suryana, Hasbianto A (2008) Usaha tani ayam buras di Indonesia: Permasalahan dan tantangan. J Litbang Pertanian 27:75-83

Tang AL, Wilcox G, Walker KZ, Shah NP, Ashton JF, Stojanovska L (2010) Phytase activity from Lactobacillus spp. in calcium-fortified soymilk. J Food Sci 75:M373-M376. doi: 10.1111/j.17503841.2010.01663.x 